\title{
Penggunaan Kembali Air Limbah - Pengolahan Air Limbah Domestik untuk Suplai Kebutuhan Air Pertanian
}

\author{
(Wastewater Reuse-Domestic Wastewater Treatment for Agricultural Water Supply)
}

\author{
Ari Sugiarto $^{1 *}$ \\ ${ }^{1}$ Departemen Teknik Sipil dan Lingkungan, IPB University, Kampus IPB Dramaga, \\ PO BOX 220, Bogor, Jawa Barat Indonesia \\ *Penulis korespondensi: sugiartoari@gmail.com
}

\begin{abstract}
Wastewater reuse arises in line with the increasing demand for water amidst the water scarcity crisis.

An alternative solution of water sources for water supply that is possible in this case is the
\end{abstract} wastewater reuse. The agricultural sector is the focus of water supply because the water quality required does not require the best water quality, but still before wastewater reuse must be treated first. The complexity of wastewater characteristics is another absolute consideration in determining the source of wastewater for water supply, domestic wastewater has characteristics that are not too complex and relatively safer than industrial wastewater. The choice of domestic wastewater also has an impact on water treatment, which in principle can be done simply, but the main problem in wastewater is related to its pollutants content. The concept of wastewater treatment with Constructed Wetland $(\mathrm{CW})$ is fairly easy to implement and the results of reducing physical and chemical pollutants are up to 40-70\%, reduction of biological pollutants is estimated to be insignificant so it needs to be combined with disinfection to reduce the content of microorganisms in the effluent which is expected to meet quality standards. The main priority is to provide water supply to agricultural land on a small scale or to be used for supporting water supply on large agricultural lands with agricultural activities that do not really need water in a continuous-time.

Keywords: Agricultural water supply, Constructed Wetland $(\mathrm{CW})+$ Disinfection, Domestic wastewater treatment, Wastewater reuse 
Kebutuhan air untuk bidang pertanian telah menjadi peruntukan air yang umum disamping peruntukan air untuk domestik dan industri, namun prioritas suplai air untuk memenuhi kebutuhan air dibidang tersebut menjadi permasalahan utama yang mungkin sampai sekarang belum terselesaikan. Kebutuhan air seperti di negera berkembang diperkirakan akan terus bertambah seiring pertambahan jumlah penduduk, pertumbuhan industri [1], dan luas lahan pertanian. Penggunaan secara berlebihan air untuk memenuhi suplai air tersebut telah menyebabkan perubahan karakteristik fisik dan kimia ekosistem perairan, daratan dan pesisir, kualitas dan kuantitas air, dan perubahan biologis langsung dan tidak langsung yang pada akhirnya menyebabkan perubahan keseimbangan air [2]. Konsekunesi lain dari Penggunaan air yang berlebih terkait penurunan kualitas air yang telah terpakai, ini menjadi permasalahan lain yang memicu terjadinya kelangkaan air. Penggunaan kembali air limbah (wastewater reuse) menjadi sebuah solusi terlihat realistis dalam menghadapi permasalahan peningkatan kebutuhan air dan kelangkaan air [3]. Penggunaan kembali air limbah juga dapat berkontribusi nyata untuk mengontrol masuknya polusi ke lingkungan [4]. Secara umum, Penggunaan kembali air limbah baru dapat dilakukan setelah melalui tahap pengolahan [5]. Berbicara tentang Penggunaan kembali air limbah untuk suplai air, masih perlu dipertimbangkan terutama terkait kualitas air hasil pengolahan. Kebutuhan air untuk domestik dan industri tentunya mengutamakan kualitas yang air baik dan jumlah yang konstan. Dalam beberapa kasus hasil pengolahan air limbah masih belum memenuhi baku mutu yang ditetapkan [6]. Secara prioritas dan ketepatan sasaran, bidang pertanian menjadi tujuan utama untuk suplai air hasil pengolahan air limbah karena tidak terlalu mempertimbangkan kualitas air yang baik. Penggunaan kembali air limbah secara umum salah satunya diarahkan utnuk suplai air pertanian [7]. Dibeberapa wilayah, kebutuhan air untuk bidang pertanian lebih banyak dibanding kebutuhan domestik dan indsutri [8]. Pemanfatan kembali air limbah untuk bidang pertanian dapat mengurangi pengunaan air bersih untuk bidang pertanian yang pada akhirnya dapat dialokasikan untuk suplai kebutuhan air domestik dan industri. 

pertanian tentunya air limbah domestik dengan pertimbangan sederhana terkait lokasi pertanian yang tidak terlalu jauh dari pemukiman penduduk Jarak dari sumber untuk suplai air dapat menjadi. parameter yang mempengaruhi potensi pemanafaatan kembali air limbah [9]. Memanfaatkan air limbah industri terkendala lokasi industri yang umumnya berada diperkotaan, sedangkan lahan pertanian sekala besar tidak berada di perkotaan. Karakteristik air limbah domestik dan industri menjadi pertimbangan utama lain dalam pemilihan sumber air limbah, karakteristik limbah industri mungkin lebih kompleks dan mengandung senyawa kimia berbahaya dibanding air limbah domestik. Volume air limbah domestik dan jumlah kebutuhan suplai air untuk bidang pertanian menjadi pertimbangan wajib untuk diperhitungkan [5]. Kendala utama dan mendasar terkait Penggunaan air limbah domestik untuk bidang pertanian terkait kekhawatiran yang ditimbulkan dari kandungan mikroorganisme dalam air limbah domestik [4]. Kandungan mikroorganisme ini dapat menjadi kontaminan dalam buah-buahan hasil panen [10].

Pengolahan air limbah domestik yang dapat mengurangi kandungan mikroorganisme dalam air limbah adalah fokus utama dalam pengolahan air limbah domestik untuk suplai air bidang pertanian. Penerapan tekenologi yang tepat dan biaya yang minimal adalah solusi utama yanga sangat dibutuhkan sekarang. Artikel ini sepenuhnya adalah hasil pemikiran dan tinjauan pustaka dari sumber-sumber ilmiah yang diharapkan dapat menjadi solusi sebagai konsep pengolahan dan Penggunaan air limbah domestik untuk suplai kebutuhan air dibidang pertanian.

\section{AIR LIMBAH DOMESTIK - KARAKTERISTIK DAN TANTANGAN PENGOLAHAN}

Secara umum karekteristik air limbah domestik meliputi parameter BOD, COD, TDS, TSS, MBAS, pH, Minyak dan lemak, Fosfat, Nitrat, Total koliform dan Fekal koliform [4, 11]. Nilai dari karakteristik air limbah ini jelas melampaui nilai karekterisik air bersih karena telah tercampur dengan proses berbagai senyawa dari kegiatan yang menggunakan air tersebut. Dalam hal ini, perubahan nilai parameter COD dan BOD dalam pengolahan air limbah menjadi salah satu tolak ukur penilaian toksisitas dalam air limbah [12]. 
Beberapa kendala yang dihadapi dalam implementasi pengolahan air limbah untuk

Penggunaan kembali air limbah mencakup penerimaan publik yang tidak memadai, risiko teknis,

ekonomi dan resiko higienis, dan ketidakpastian lebih lanjut yang disebabkan kurangnya kesadaran,

81 baku mutu, pedoman dan undang-undang yang seragam [13]. Resiko yang menjadi fokus

82 Penggunaan kembali air limbah domestik salah satunya terkait pada resiko biologis, seperti bakteri

83 (Fekal koliform, Total koliform, Legionella sp.), virus (Enterovirus dan Bacteriophages), dan

84 nematoda yang mungkin menjadi resisten terhadap pengolahan air limbah konvensional seperti

85 Chlorination $[11,14]$. Selain itu keterlambatan penerapan program penggunaan kembali air limbah 86 juga menjadi tantangan dalam pengolahan air limbah. [15].

\section{BAKU MUTU AIR DAN PERUNTUKAN KELAS AIR UNTUK PERTANIAN}

Studi kasus di Indonesia, dalam Peraturan Pemerintah No 82 Tahun 2001 tentang

Pengelolaan kualitas air dan pengendalian pencemaran air diklasifikasikan menjadi 4 kelas [16], yaitu:

- Kelas satu, air yang peruntukannya dapat digunakan untuk air baku air minum, dan atau peruntukan lain yang memper-syaratkan mutu air yang sama dengan kegunaan tersebut.

- Kelas dua, air yang peruntukannya dapat digunakan untuk prasarana/sarana rekreasi air, pembudidayaan ikan air tawar, peternakan, air untuk mengairi pertanaman, dan atau peruntukan lain yang mempersyaratkan mutu air yang sama dengan kegunaan tersebut.

- Kelas tiga, air yang peruntukannya dapat digunakan untuk pembudidayaan ikan air tawar,

- Kelas empat, air yang peruntukannya dapat digunakan untuk mengairi pertanaman dan atau peruntukan lain yang mempersyaratkan mutu air yang sama dengan kegunaan tersebut. 
Table 1. Baku mutu air limbah domestik

\begin{tabular}{lll}
\hline Parameter & Satuan & Kadar maksimum \\
\hline $\mathrm{pH}$ & - & $6-9$ \\
$\mathrm{BOD}$ & $\mathrm{Mg} / \mathrm{l}$ & 30 \\
$\mathrm{COD}$ & $\mathrm{Mg} / \mathrm{l}$ & 100 \\
$\mathrm{TSS}$ & $\mathrm{Mg} / \mathrm{l}$ & 30 \\
Minyak dan Lemak & $\mathrm{Mg} / \mathrm{l}$ & 5 \\
Amoniak & $\mathrm{Mg} / \mathrm{l}$ & 10 \\
Total Koliform & $\mathrm{Jumlah} / 100 \mathrm{ml}$ & 3000 \\
Debit & $\mathrm{L} /$ orang/hari & 100
\end{tabular}

Sumber: [17]

109 Namun mungkin untuk peraturan baku mutu air limbah domestik (Table 1) yang dikeluarkan oleh

110 masing-masing daerah nilai batas masimumnya lebih kecil dari batas minimum ditetapkan dalam

111 Peraturan Menteri Lingkungan Hidup dan Kehutanan No 68 Tahun 2016 yang bertujuan mencegah

112 terjadi pencemaran air. Baku mutu pencemaran air dimuat dalam Peraturan Pemerintah No 82 Tahun $1132001[16]$.

114

115 Table 2. Baku mutu kualitas air

\begin{tabular}{llllll}
\hline Parameter & Satuan & \multicolumn{4}{c}{ Kelas } \\
\cline { 3 - 6 } & & I & II & III & IV \\
\hline Fisika & & & & & \\
\hline Temperatur & ${ }^{\circ} \mathrm{C}$ & Deviasi 3 & Deviasi 3 & Deviasi 3 & Deviasi 5
\end{tabular}




\begin{tabular}{llllll} 
TDS & Mg/l & 1000 & 1000 & 1000 & 2000 \\
TSS & Mg/l & 50 & 50 & 400 & 400 \\
\hline Kimia Anorganik & & & & & \\
\hline $\mathrm{pH}$ & - & $6-9$ & $6-9$ & $6-9$ & $5-9$ \\
BOD & $\mathrm{Mg} / 1$ & 2 & 3 & 6 & 12 \\
$\mathrm{COD}$ & $\mathrm{Mg} / \mathrm{l}$ & 10 & 25 & 50 & 100 \\
DO & $\mathrm{Mg} / \mathrm{l}$ & 6 & 4 & 3 & 0 \\
\hline Mikrobiologi & & & & & \\
\hline Fekal Koliform & Jumlah/100 ml & 100 & 1000 & 2000 & 2000 \\
Total Koliform & Jumlah/100 ml & 1000 & 5000 & 10000 & 10000 \\
\hline
\end{tabular}

Sumber: [16]

118 Baku mutu air limbah domestik jelas lebih kecil nilainya dari pada baku mutu pencemaran air untuk

119 kelas IV ( Table 2) yang merupakan kelas air yang diperuntukkan untuk mengairi tanaman.

\section{PENGOLAHAN AIR LIMBAH DOMESTIK: TINJAUAN SINGKAT}

Pengolahan air limbah menjadi faktor penting dalam pememanfatan kembali air limbah

122 domestik. Pemilihan proses pengolahan yang tepat (efisien dan praktis) menjadi pilihan utama yang

123 mutlat. Proses-proses dalam tahapan pengolahan air limbah menjadi faktor lain yang harus

124 dipertimbangkan selain yang utama adalah desain unit pengolahan air limbah itu sendiri.

\section{Alternatif Pengolahan}

Pengolahan air limbah domestik untuk suplai air pertanian dapat menggunakan beberapa

127 alternatif pengolahan yang sering dikombinasikan seperti Desinfeksi Ultraviolet (UV), Constructed

128 Wetland (CW), Chlorination (Chlo), Granular Activated Carbon (GAC), Depth filter (DF),

129 Dissolved Air Flotation (DAF), Ultrafiltrasi (UF), Reverse osmosis (RO), dan Koagulasi/flokulasi

$130[18,19]$. Penggunaan teknologi UF pada Penggunaan kembali air limbah adalah sesuatu yang mahal,

131 namun reduksi polutan dalam air limbah seperti COD sangat baik diterapkan dalam pengolahan air 
132 limbah yang mampu mereduksi sampai 99\% [20], selain itu juga sangat efektik dalam mereduksi

133 kandungan bakteri dalam air limbah sampai pada titik 0 [21]. Pengolahan air limbah menggunakan

134 CW cukup efektif dalam menurunkan polutan seperti TS, COD, dan LAS sekitar 40-70 \%, selain itu

135 prinsip dasar perancangan $\mathrm{CW}$ yang tujuannya adalah pengolahan air limbah dan estetika terkait

136 penggunaan tanaman dalam unit pengolahan [22]. Penerapan penglohan air limbah dengan CW,

137 seperti di Turki menjadi pilihan yang cukup dominan dibanding dengan pilihan pengolahan air

138 lainnya [23]. Pengelohan air limbah domestik dengan CW terlihat ramah lingkungan, ini menjadi

139 nilai tambah tersendiri dalam pilihan tersendiri yang meminimalkan opini negatif dari unit

140 pengolahan air limbah. Penggunaan tanaman dapat menambah nilai Green suatu bangunan, sehingga

141 kombinasi nilai tambah inilah yang sebenarnya sedang dibutuhkan.

142 Konsep pengolahan air limbah domestik dengan CW menjadi fokus utama yang dapat

143 dikembangkan lebih lanjut, hanya saja perlu mempertimbangkan lebih lanjut terkait resiko biologis

144 dalam air limbah. Kandungan Fekal koliform dan Total koliform menjadi permasalahan lain yang

145 harus diselesaikan. Desinfeski dapat menjadi kombinasi dalam pengolahan air limbah domestik

146 dengan $\mathrm{CW}$, kombinasi keduanya memungkinkan menghasilkan efluent yang dapat memenuhi baku

147 mutu yang telah ditetapkan [18]. Tahapan lanjut dari implementasinya adalah bagaimana merancang

148 desain yang tepat untuk dapat menjadi suatu unit pengolahan air limbah.

149 Proses Pengolahan Air Limbah Domestik - Kombinasi Constructed Wetland $($ CW $)+$ Desinfeksi

150 Tahapan pengolahan air limbah domestik meliputi Secondary treatment, Tertiary treatment,

151 dan Quaternary treatment [24]. Proses umum dalam suatu tahapan pengolahan air limbah meliputi

152 beberapa tahapan yaitu influent, grit and grease removal, biological treatment, sedimentasi dan

153 sludge production, send filtery dan desinfeksi, dan efluent [25], dalalm versi lainnya pengolahan air

154 limbah meliputi influent, anaerobik reaktor, separasi, ammonia-rich supernatant, lumpur aktif dengan

155 sequnesing substrat organik, reaktor nitrifikasi biofilm, denitrifikasi, aerasi, final clarifier, dan

156 effluent [26]. Dalam pengolahan air limbah domestik dengan CW secara singkat dimulai dari influent, 
157 sedimentasi, filtrasi, dan efluent [22]. Pola aliran air dalam pengolahan air limbah domestik dengan

158 CW digolongkan menjadi 2, yaitu pola aliran horizontal dan vertikal (Gambar 1).

159
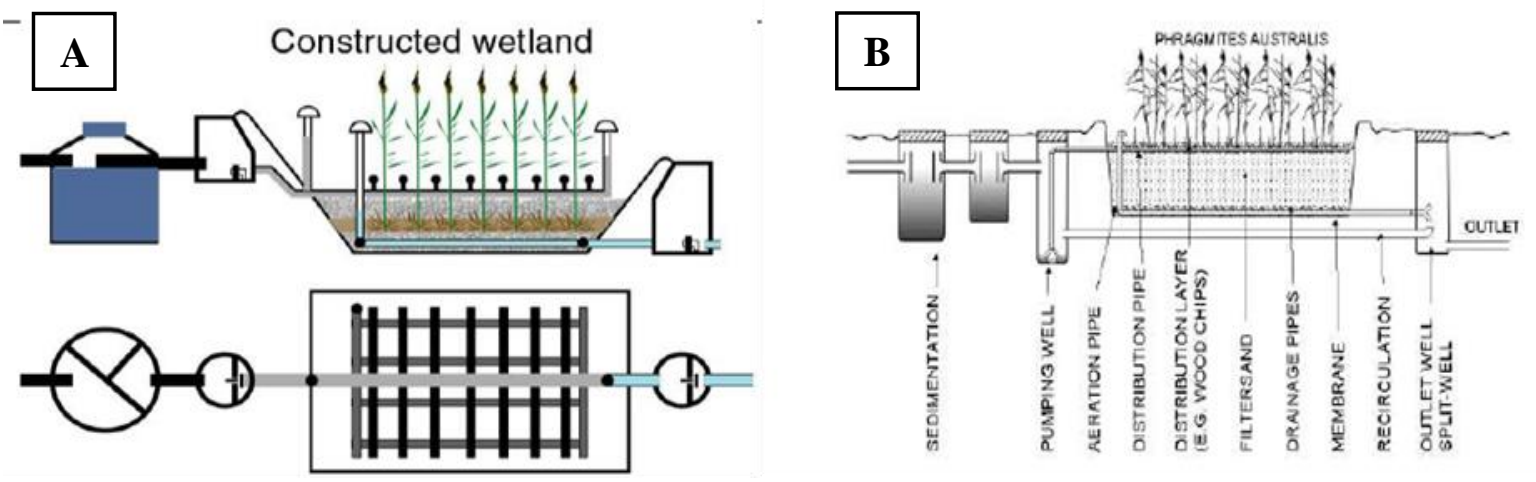

160

Gambar 1.Constructed Wetland (CW)-(A). Pola aliran horizontal, (B). Pola aliran vertikal [22]

162

163

Efluent yang dihasilkan dari pengolahan air limbah ditampung dalam reservoir, desain penentuan kapasitas CW perlu diperhitungkan lebih lanjut untuk teknis detailnya.

Perancangan konstruksi CW dapat dikombinasikan seperti kerikil, pets, arang, sekam, zeolit dan lain-lain sesuai dengan tujuan penggunaan CW [22]. Beberapa tanaman yang dapat dipakai dalam pengolahan air limbah dengan CW seperti Cupressus Sempervirens, Juniperus Horizontalis, 27], dan lain-lain.

Hasil pengolahan air limbah domestik dengan CW terbilang cukup baik dengan mampu menurunkan polutan 40-70\% [22]. Reduksi polutan dalam air limbah dengan CW dapat dilihat pada

172 Table 3.

173

174 Table 3. Perbandingan Influent dan Efluent pada pengolahan air limbah domestik dengan Constructed Wetland 175 $(\mathrm{CW})$

\begin{tabular}{llll}
\hline Parameter & Satuan & Influent & Efluent \\
\hline Salinitas & $\mathrm{g} / \mathrm{l}$ & 1 & 0,8
\end{tabular}




$\begin{array}{lccc}\text { DO } & \mathrm{Mg} / 1 & 3,01 & 0,08 \\ \text { TDS } & \mathrm{Mg} / 1 & 1257 & 1084 \\ \text { BOD } & \mathrm{Mg} / \mathrm{l} & 104 & 0,33 \\ \mathrm{TSS} & \mathrm{Mg} / \mathrm{l} & 2,55 & 9\end{array}$

178 Hasil pengolahan ini belum dapat memastikan reduksi Total koliform dan Fekal koliform dalam air

179 limbah, sehingga desinfeksi efluent yang tertampung pada reservoir adalah langkah yang tepat untuk

180 dapat mereduksi Total koliform dan Fekal koliform dalam air efluent. Catatan penting harus 181 diperhatikan disini adalah jenis disenfeksi yang akan dipilih, jika menggunakan klorid tentu harus 182 menentukan jumlah yang tepat sehingga nanti jika air digunakan untuk suplai air di bidang pertanian 183 tidak menjadi masalah terhadap tanaman.

184 Penerapan pengolahan air limbah domestik CW + desinfeksi dinilai sangat baik untuk 185 dilakukan ini ditunjukkan dengan nilai utilitas dari kombinasi teknologi pengolahan air limbah 186 dengan $\mathrm{CW}+$ desinfeksi sangat baik hasilnya dibanding kombinasi lain [18]. Hasil lainnya masih 187 sangat bergantung dengan desain yang tepat dan pemilihan tanaman yang memiliki sifat akumulator 188 yang tinggi dan dapat beradaptasi baik pada lingkungan yang tercemar akan sangat baik untuk 189 diterapkan.

190 PENGgUNAAN KEMBALI AIR LIMBAH: SEBUAH SOLUSI UNTUK SUPLAI AIR 191 PERTANIAN?

192 Kesadaran penggunaan kembali air limbah muncul seiring meningkatnya permintaan sumber 193 air dan kelayakan menghasilkan pemurnian tinggi air menggunakan teknologi modern [28]. 194 Ketersediaan air adalah faktor penting yang mendukung terlaksananya kegiatan di bidang pertanian. 195 Meningkatan suplai air jelas akan berdampak pada peningkatan ketahanan pangan, ketersediaan air 196 pada lahan pertanian kering dan semi-kering jelas menjadi pembatas [29]. 

polutan [30]. Sudut pandang lain membuka pemikiran bahwa kandungan fosfor, nitrogen dan material organik dalam air limbah domestik dapat mendukung pertumbuhan tanaman, peluang ini memungkinkan Penggunaan kembali air limbah domestik untuk suplai air di bidang pertanian [4]. Peruntuk air hasil pengolahan air limbah untuk suplai air pertanian tentunya harus memenuhi kriteria yang ada (Table 4) agar meminimalisir dampak negatif yang tidak diinginkan.

204 Table 4. Kualitas air untuk suplai air pertanian

\begin{tabular}{lll}
\hline Paraneter & Satuan & Ambang batas (nilai tengah) \\
\hline Salinitas & $\mathrm{dS} / \mathrm{m}$ atau $\mu \mathrm{mhos} / \mathrm{cm}$ & $0.7-3.0$ \\
$\mathrm{TDS}$ & $\mathrm{mg} / \mathrm{l}$ & $450-2000$ \\
$\mathrm{TSS}$ & $\mathrm{mg} / \mathrm{l}$ & $50-100$ \\
Bikarbonat $\left(\mathrm{HCO}_{3}\right)$ & $\mathrm{mg} / 1$ & $90-500$ \\
Klorida & $\mathrm{mg} / 1$ & $140-350$ \\
Hidrogen Sulfida $\left(\mathrm{H}_{2} \mathrm{~S}\right)$ & $\mathrm{mg} / 1$ & $0.5-2.0$ \\
Besi (Fe) & $\mathrm{mg} / 1$ & $0.1-1.5$ \\
Nitrogen $(\mathrm{N})$, & $\mathrm{mg} / 1$ & $5-30$
\end{tabular}

207 Teknologi yang mendukung dapat menjadi kunci utama dalam menerapkan konsep pengolahan air

208 limbah domestik untuk suplai air pertanian [31]. Langkah lain yang tidak kalah penting adalah 209 membuat dan menegakkan standar penggunaan air limbah di bidang pertanian [32].

210 Tinjauan singkat peluang Penggunaan air limbah domestik untuk suplai sangat 211 memungkinkan untuk dimplementasikan. Keberhasilan implementasi Penggunaan kembali air 212 limbah domestik untuk suplai air pertanian akan memunculkan dampak positif yang besar, mengatasi

213 kelangkaan air untuk suplai air di bidang pertanian adalah bukti nyatanya dan sektor domestik dan 
214 industri dapat mengalokasikan air bersih untuk keperluannya tanpa khawatir akan tumbul

215 permasalahan kebutuhan air untuk domestik, industri, dan pertanian.

\section{PRIORITAS SUPLAI AIR PERTANIAN}

217 Penggunaan kembali air limbah biasanya diperuntukkan untuk mendukung suplai air irigasi 218 pertanian dan campuran air untuk suplai irigasi pertanian, irigasi area lansekap, industri reuse and 219 recycle, pengsisian air tanah (groundwater rechrage), lingkungan (danau dan kolam, augmentasi 220 aliran sungai, dan perikanan), non-potable urban uses (proteksi kebakaran, pendingin udara, dan menyiram toilet), dan potable reuse (campuran suplai air reservoir dan suplai air perpipaan) [13, 24, 33, 34]. Volume yang dihasilkan dari unit pengolahan air limbah menjadi pertimbangan lain terkait prioritas suplai air. Konsep yang mungkin untuk diterapkan adalah prioritas suplai air untuk lahan

224 pertanian dalam skala kecil atau digunakan untuk suplai air pendukung pada lahan pertanian yang besar, namun peruntukan lebih detail lagi dapat diperuntukan untuk pertanian yang tidak terlalu membutuhkan air dalam waktu yang terus menerus.

\section{KESIMPULAN}

Penggunaan kembali air limbah domestik menjadi alternatif yang sangat memungkinkan untuk suplai air di bidang pertanian ditengah meningkatnya kebutuhan air dari dampak perluasan 230 lahan pertanian. Kandungan nitrogen, fosfor, dan material organik dalam air limbah dapat menjadi 231 pendukung unsur hara tanaman. Karakteristik air limbah domestik yang tidak terlalu komplek membuat pengolahan air limbah dapat dilakukan dengan prinsip sederhana. Konsep CW + desinfeksi menjadi alternatif yang terlihat menjanjikan dalam pengolahan air domestik dengan mereduksi

234 polutan sangat baik terutama parameter fisik dan kimia, mereduksi parameter biologis dilakukan 235 dengan desinfeksi. Konsep ini juga menjadi alternatif dalam menambah nilai estetika dan 236 berkelanjutan terkait penggabungan prinsip pengolahan air limbah dan penambahan tanaman.

237 Prioritas utama untuk suplai air pada lahan pertanian dalam skala kecil atau digunakan untuk suplai 238 air pendukung pada lahan pertanian yang besar, dengan kegiatan pertanian yang tidak terlalu membutuhkan air dalam waktu yang terus menerus. Pencapaian akhir dari penggunaan kembali air 
limbah domestik untuk pertanian adalah penghematan penggunaan air bersih untuk suplai air di

241 bidang pertanian, ketersediaan air ini dapat dialokasikan untuk suplai air domestik dan industri.

242

243

244

\section{UCAPAN TERIMA KASIH}

Penulisan artikel ini sangat terbantu dengan masukan dan saran yang diberikan oleh Dr.Eng.

Allen Kurniawan, ST., MT terutama terkait Teknik Pengolahan Air Limbah.

\section{DAFTAR PUSTAKA}

[1] N. Kretschmer, L. Ribbe and H. Gaese, "Wastewater Reuse in Agriculture," Technology Resource Management \& Development-Scientific Contributions for Sustainable Development, vol. 2, pp. 37-64, 2002.

[2] F. Malin, C. M. Finlayson, J. Line, M. Elena, M. Tabeth, C. David, G. Nilanjah, M. Gopalakrishnan, S. Rudolf, J. Gunnar, K. Eloise, O. Lekan, M. Michael, D. Garry, M. Jorge, S. Kemi, T. Rebecca and W. Robert, "Agriculture, Water, and Ecosystems: Avoiding the Costs of Going too Far," in Water for Food Water for Life: A Comprehensive Assessment of Water Management in Agriculture, London dan Colombo, Earthscen dan International Water Management Institute., 2007, pp. 233277.

[3] O. Gonza'lez, B. Bayarri, J. Acena, S. Pe'rez and D. Barcel, "Treatment Technologies for Wastewater Reuse: Fate of Contaminants of Emerging Concern," in Advanced Treatment Technologies for Urban Wastewater Reuse, Springer, Chem, 2015, pp. 537.

[4] B. J. Cisneros, "Wastewater Reuse to Increase Soil Productivity," Water Science \& Technology, vol. 32, no. 12, pp. 173-180, 1995.

[5] H. Yang and C. A. Karim, "Analysis of Wastewater Reuse Potential in Beijing," Desalination, vol. 212, no. 1-3, pp. 238-250, 2007.

[6] D. Susanthi, M. Y. J. Purwanto and Suprihatin, "Evaluasi Pengolahan Air Limbah Domestik Dengan IPAL Komunal Di Kota Bogor," Jurnal Teknologi Lingkungan, vol. 19, no. 2, pp. 229-238, 2018.

[7] L. Zhao, D. Tianjiao, Q. Zhi, S. Peizhe, H. Jianye and Y. Yongkui, "Application of Artificial Intelligence to Wastewater Treatment: A Bibliometric Analysis and Systematic Review of Technology, Economy, Management, and Wastewater Reuse," Process Safety and Environmental Protection, vol. 133, pp. 169-182, 2020.

[8] M. Meneses, C. P. Jorgelina and C. Francesc, "Environmental Assessment of Urban Wastewater Reuse: Treatment Alternatives and Applications," Chemosphere, vol. 81, p. 266-272, 2010. 
[9] J. R. Adewumia, A. Ilemobadea and J. E. V. Zylb, "Treated Wastewater Reuse in South Africa: Overview, Potential and Challenges," Resources, Conservation and Recycling, vol. 55, pp. 221-231, 2010.

[10] G. L. Cirelli, S. Consoli, F. Licciardello, R. Aiello, F. Giuffrida and C. Leonardi, "Treated municipal wastewater reuse in vegetable production.," Agricultural Water Management, vol. 104, pp. 163-170, 2012.

[11] M. Salgot, E. Huertas, S. Weber, W. Dott and J. Hollender, "Wastewater Reuse and Risk: Definition of Key Objectives," Desalination, vol. 187, no. 1-3, p. 29-40, 2006.

[12] Y. Xiao, D. A. Cecilia, C. Z. Chun and C. S. David, "Toxicity Measurement in Biological Wastewater Treatment Processes: A Review," Journal of Hazardous Materials, vol. 286, pp. 15-29, 2015.

[13] T. Wintgens, T. Melin, A. I. Schäfer, M. Muston, D. Bixio and C. Thoeye, "The Role of Membrane Processes in Municipal Wastewater Reclamation and Reuse," Desalination, vol. 178, pp. 1-11, 2005.

[14] C. Caicedo, K. H. Rosenwinkel, M. Exner, W. Verstraete, R. Suchenwirth, P. Hartemann and R. Nogueira, "Legionella Occurrence in Municipal and Industrial Wastewater Treatment Plants and Risks of Reclaimed Wastewater Reuse: Review," Water Research, vol. 149, pp. 21-34, 2019.

[15] S. Lyu, C. Weiping, Z. Weiling, F. Yupeng and J. Wentao, "Wastewater Reclamation and Reuse in China: Opportunities and Challenges," Journal of Environmnetal Sciences, vol. 39, pp. 86-96, 2016.

[16] Presiden Republik Indonesia, Peraturan Pemerintah Republik Indonesia Nomor 82 Tahun 2001, Jakarta: Presiden Republik Indonesia, 2001.

[17] Menteri Lingkungan Hidup dan Kehutanan Republik Indonesia, Peraturan Menteri Lingkungan Hidup dan kehutanan Rebublik Indonesia Nomor: P.68/MenlhkSetjen/2016 tentang Baku Mutu Air Limbah Domestik, Jakarta: Menteri Lingkungan Hidup dan Kehutanan Republik Indonesia, 2016.

[18] A. Akhoundi and N. Sara, "Sustainability Assessment of Wastewater Reuse Alternatives Using the Evidential," Journal of Cleaner Production, vol. 195, pp. 13501376, 2018.

[19] M. P. D. Pino and D. Bruce, "Wastewater Reuse Through Dual-membrane Processes: Opportunities for Sustainable Water Resources," Desalination, vol. 124, pp. 271-277, 1999.

[20] J. M. Gozálvez-Zafrilla, D. Sanz-Escribano, J. Lora-García and M. L. Hidalgo, "Nanofiltration of Secondary Effluent for Wastewater Reuse in the Textile Industry," Desalination, vol. 222, no. 1-3, pp. 272-279, 2008.

[21] A. Nocker, L. Schulte-Illingheim, H. Müller, A. Rohn, B. Zimmermann, A. Gaba, A. Nahrstedt, H. Mohammadi, Y. Tiemann and K. Krömer, "Microbiological Changes Along a Modular Wastewater Reuse Treatment Process with a Special Focus on Bacterial Regrowth," Journal of Water Reuse and Desalination, 2020. 
[22] A. C. S. P. Suswati and W. Gunawan, "PENGOLAHAN LIMBAH DOMESTIK DENGAN TEKNOLOGI TAMAN TANAMAN AIR (Constructed Wetlands)," Indonesian Green Technology Journal, vol. 2, no. 2, pp. 70-77, 2013.

[23] B. Maryam and B. Hanife, "Wastewater Reclamation and Reuse Trends in Turkey: Opportunities and Challenges," Journal of Water Process Engineering, vol. 30, p. 100501, 2019.

[24] D. Bixio, C. Thoeye, J. De Koning, D. Joksimovic, D. Savic, T. Wintgens, Melind and T, "Wastewater Reuse in Europe," Desalination, vol. 187, no. 1-3, p. 187, 2006.

[25] S. Magni, B. Andrea, P. Lucia, G. A. Carlo, D. T. Camilla, C. P. Camilla, S. G and R. Francesco, "The Fate of Microplastics in an Italian Wastewater Treatment Plant," Science of the Total Environment, vol. 652, p. 602-610, 2019.

[26] J. Wanner, J. S. Cech and M. Kos, "New Proccess Design for Biological Nutrient Removal," Water Science and Technology, vol. 25, no. 4-5, pp. 445-448, 1992.

[27] C. Lubelloa, G. Riccardo, P. N. Francesco and F. Francesco, "Municipal-treated Wastewater Reuse for Plant Nurseries Irrigation," Water Research, vol. 38, p. 29392947, 2004.

[28] K. Madwar and T. Hani, "Desalination techniques for industrial wastewater reuse," Desalination, vol. 152, pp. 325-332, 2002.

[29] N. R. Mizyed, "Challenges to Treated Wastewater Reuse in Arid and Semi-arid Areas," Environmental Science \& Policy, vol. 25, pp. 186-195, 2013.

[30] B. Jimenez, "Treatment technology and standards for agricultural wastewater reuse: a case study in Mexico," Irrigation and Drainage: The journal of the International Commission on Irrigation and Drainage, vol. 54, no. S1, pp. S23-S33, 2005.

[31] A. Alfarra, E. Kemp-Benedict, H. Hötzl, N. Sader and B. Sonneveld, "A Framework for Wastewater Reuse in Jordan: Utilizing a Modified Wastewater Reuse Index," Water Resources Management, vol. 25, no. 4, pp. 1153-1167, 2011.

[32] A. Kajenthira, S. Afreen and D. A. Laura, "A New Case for Promoting Wastewater Reuse in Saudi Arabia: Bringing Energy Into the Water Equation," Journal of Environmental Management, vol. 102, pp. 184-192, 2012.

[33] J. A. Faby, F. Brissaud and J. Bontoux, "Wastewater Reuse in France: Water Quality Standards and Wastewater Technology," Water Science and Technology, vol. 40, no. 4-5, pp. 37-42, 1999.

[34] A. Alfarra, K. B. Eric and H. Heinz, "A Framework for Wastewater Reuse in Jordan: Utilizing a ModifiedWastewater Reuse Index," Water Resour Manage, vol. 25, no. 4, p. 1153-1167, 2011. 